\title{
ECONOMIC AND LEGAL FRAMEWORK OF PROMOTION OF FAMILY FARMING
}

\author{
Yuliya Koverko ${ }^{1}$, Vasyl Andriyiv², Galyna Martynyshyn ${ }^{3}$ \\ ${ }^{1}$ Associate professor, Dr., Stepan Gzhytskyi National University of Veterinary Medicine and \\ Biotechnologies Lviv, Lviv, Pekarska street, 50, Ukraine. \\ Tel.: +3809794 53 910, E-mail ukov@ukr.net \\ ${ }^{2}$ Prof., Dr. Hab., Jan Kochanowski University in Kielce, Poland. E-mail: adriivv@gmail.com \\ ${ }^{3}$ Associate professor, Lviv Institute of Economy and Tourism, Ukraine. \\ E-mail: martynyshyn_g@ukr.net
}

Received 0211 2019; accepted 20122019

Family farming is the world's most popular and widespread form of farming. However, this category of agricultural producers officially exists in Ukraine since 2016. Notwithstanding the fact that the legal framework for regulation of activity of family farms has already been developed, the process of establishment such farms remains very slow. Therefore, the main objective of this article is to investigate the economic and legal framework for promotion of family farming. The technical legal method was used for this purpose to analyze the regulatory framework of establishment and operation of family farms and the social method to discover reasons that hinder the process of evolvement of family farms. The use of the method of legal modelling enabled us to identify the activities that can stimulate creation of such farms, such as development and approval of financial support schemes, access to markets and land resources, information support, tax preferences, etc.

Keywords: family farm, private farm household, state support, stimulation.

JEL Codes: Q12, Q18, K10.

\section{Introduction}

Family farming is one of the world's most popular and widespread forms of farming. According to The Food and Agriculture Organization of the United Nations (FAO), family farms represent $88 \%$ of the world's farming agents and employ approximately $40 \%$ of the working population. Family farms produce $56 \%$ of the world's agricultural products and supply the majority of the world's agricultural markets with products. The farms cultivate $83 \%$ of agricultural lands in the Northern and Central America, 68\% of agricultural lands in Europe, $85 \%$ of agricultural lands in Asia and $62 \%$ of agricultural lands in Africa (Korinets, 2018).

According to the definition by FAO, «family farming is a means of organizing agricultural, forestry, fisheries, pastoral and aquaculture production which is managed and operated by a family and predominantly reliant on family labour, including both women's and men's» (Family..., 2014).

Copyright (C) 2019 The Authors. Published by Vytautas Magnus University. This is an open-access article distributed under the terms of the Creative Commons Attribution-NonCommercial 4.0 (CC BY-NC 4.0) license, which permits unrestricted use, distribution, and reproduction in any medium, provided the original author and source are credited. The material cannot be used for commercial purposes. 
The defining characteristic of a family farm is that it produces agricultural products using family labour, generates income from family labour that is comprised of labour remuneration and proceeds from farming, represents a place of education and acquisition of knowledge, protects the local culture by acting as a guarantor of food safety and economic basis of the rural area. Large, corporation style farms are regarded as highly specialised and intensive monocultures. Contrary to the abovementioned, family farms tend to be smaller and less specialised, therefore ensuring greater biodiversity and with a higher labour input, a greater contributor to rural employment and the social fabric of rural areas (CAP...).

Predomination of the farmers' households as family business organizations, dependency of agricultural activities and results on natural environment, multifunctional nature of agricultural activities, measurements of financial assistance and other factors distinguish the farmers' households from other business organizations (Zaleckienè, 2018).

The fact that family farmers are not a defined group in most countries is a major challenge (Graeub, 2016). The institutional formalization of family farms in Ukraine is still continuing. Although the legal framework regulating the procedure of establishment and operation of family farms has already been developed, some of its regulations, i.e. stimulation of establishment of family farms, need clarification and improvement, since the process of establishment of a business pattern, which is new for the Ukrainian legislation, is still very slow.

The issue of establishment and operation of family farms in Ukraine has already been investigated by many researchers for a long period of time. In particular, the issue of legal regulation of establishment and functioning of family farms was studied by such academic lawyers as Lushpaiev (Lushpaiev, 2018), Urkevych (Urkevych, 2016), Khrypko (Khrypko, 2015), Dolynska (Dolynska, 2017). The issues of formalization of family farming were addressed in papers of such experts of the agrarian economics as Prokopa, Borodina (Borodina, 2018), Korinets (Korinets, 2018), Malik, Shpykuliak, Mamchur (Malik, 2018). These scholars analyzed the novelties of the legislation related to establishment of family farms and identified business and practical fundamentals of their development. However, the problem of promotion of family farming, especially by means of transformation of private farm households, still remains an urgent challenge.

This article is aimed at the complex research of economic and legal framework for promotion of family farming. For this purpose, the technical legal method was used to analyze the legal standards that regulate the procedure of establishment and operation of family farms and the social method was used to discover reasons that hinder the process of evolvement of family farms. We obtained empirical data using the sociological method on the prospects of transformation of personal farms into family farms. A sociological survey of members of private farms was conducted in 2016 in the framework of the research work (Koverko, 2016) in six villages of the Lviv region. The selection of representative villages was carried out by the method of expert evaluation, while the selection considered the socio-economic characteristics 
and location of the objects of study. The selection of respondents was made using the random number method, followed by adjustments with the aim of better representativeness. The structure of the respondents according to age, employment, size of the farm, land area, purpose of maintaining a personal peasant economy generally corresponded to the population structure of the area. 180 people of working age were interviewed during the survey. The results of the survey revealed the frequent personal farms that have the prospect of development in the status of family farms, as well as identify problems that impede transformation processes.

Measures to support family farms in the Republic of Poland and Ukraine were compared using the comparative method. The use of the legal modeling method has led to the development of proposals for the creation of institutional and economic conditions that would facilitate the creation and development of family farms in Ukraine.

\section{Results}

The agricultural sector of Ukraine is characterized by a variety of agents producing agricultural products (agricultural enterprises, farms, private farm households). In the structure of agricultural production by categories of agents, the share of agricultural enterprises (including large farms operating based on the hired labour) constitutes $56,4 \%$, the share of private farm households $-43,6 \%$.

Currently, private farm households are the main representatives of family farming in Ukraine. In accordance with the Law of Ukraine No.742-IV «On Private Farm Households» as of May 15, 2003, the economic activity of such households is carried out without registration of a legal entity by an individual or individuals having family or kindred relationship and living together for the purpose of satisfaction of personal needs by means of production, processing and consumption of agricultural products, sale of surplus of such products and provision of services using the property of private farm households, including services in the sphere of the green tourism.

There were 4031,7 thousand private farm households in Ukraine owning 6175,6 thousand hectares of lands, including 2551,3 thousand hectares of lands for personal farming and 2799,3 thousand hectares of lands for commercial agriculture. In the structure of private farm households, households with the area of land plots under 0,5 ha represent $51,3 \%$ of all households, households with the area of land plots from 0,51 to 1 ha $-28 \%$, households with the area of land plots over 1 ha $20,7 \%$.

Depending on the business purpose, private farm households are divided into consumer households, medium-level households and industrialized farms (Hubeni, 2016). Mostly, the main objective of a private farm household is to provide a family with food products. However, the results of our survey show that $15,9 \%$ of farm households aim to earn additional income, while 7,3\% of households have an obvious business motivation - earning of the primary income. 
Private farm households do not have a status of agricultural producers, they are small in size and have a low level of labour mechanization and prevailing manual labour. They remain the main producers of many types of agricultural products (vegetables, milk, fruit and berry crops, etc.), therefore supporting the food safety of the country. However, we observe a negative dynamic growth in the recent years. An important reason for this is the migration of the working-age population from countryside due to the high level of unemployment. As a result, the birth level is decreased, resulting in the gradual aging of the rural population and depression of villages.

Transformation into family farms can be one of the ways of further development of private farm households and preservation of Ukrainian villages.

Having signed Association Agreement with the European Union, European Atomic Energy Community and their member states in 2014, Ukraine assumed obligations to introduce political, socio-economic, legal and institutional reforms for the purpose of modernization of all spheres of the public life. The Agreement provides for the following initiatives in the sphere of agriculture and development of rural territories: promotion of mutual understanding of policies in the sphere of agriculture and development of rural territories; intensification of administrative abilities at the central and local levels in the realm of planning, assessment and implementation of the policy; exchange of knowledge and best practices related to the policy of development of rural territories for the purpose of fostering of the economic welfare of rural communities; increase of competitiveness of the agricultural industry, efficiency and transparency of markets, as well as improvement of the investment conditions; spreading of knowledge by implementation of educative and information initiatives; exchange of the best practices related to the mechanisms of support of the policy in the sphere of agriculture and development of rural territories, etc.

According to Article 4 of the Regulation (EU) No. 1307/2013 of the European Parliament and of the Council as of 17 December 2013, a «farmer» means a natural or legal person, or a group of natural or legal persons, regardless of the legal status granted to such group and its members by national law, who perform agricultural activity (Regulation..., 2013). Therefore, it is obvious that the Association Agreement became an accelerator of formalization of family farming in Ukraine. As a result, the Ministry of the Agrarian Policy and Food of Ukraine has developed the Single and Comprehensive Strategy and Action Plan for Agriculture and Rural Development in Ukraine for 2015-2020, aiming at increase of competitiveness of agriculture and promotion of the balanced development of rural territories in line with the international and European standards, in particular by way of legalization of family farms, granting them access to the system of state support of the agrarian sector, social protection and security, as well as other types of support.

In 2016, the government of Ukraine adopted the Law No.1067-VIII «On Introduction of Amendments to the Law of Ukraine «On Farming» Relative to Stimulation of Establishment and Operation of Farms» of March 31, 2016 that 
differentiates a family farm as a separate type of farming with possibility of operation as a legal entity or an individual entrepreneur. In accordance with the Law, a farm household registered as a legal entity or an individual entrepreneur has a status of a family farm if it uses labour of family members of such household that belong to one family. Other persons can be engaged by such family farm only for seasonal or individual works that are directly related to the operation of the farm and require special knowledge or skills.

However, establishment of family farms actually was impossible for two years, since the statutory regulations of establishment and operation of family farms contained a number of legal disadvantages (in particular, the procedures of regulation of internal relations in the farm household, acquisition and termination of the membership right, etc. were absent).

On July 10, 2018, the government of Ukraine adopted the Law No. 2497-VIII «On Introduction of Amendments to the Tax Code of Ukraine and Some Other Laws on Stimulation of Establishment and Operation of Farm Households» aimed to eliminate the defects of statutory regulations.

In accordance with this Law, a family farm without the status of a legal entity is organized by an individual personally or jointly with other family members based on a contract (declaration) on establishment of a family farm. The contract on establishment of a family farm is concluded in writing by an individual jointly with other family members and is subject to notarization at the place of location of the property and land plots of the family farm. In case the farming activity is carried out only by an individual, a declaration on establishment of a family farm is executed in a written form. The head of a family farm household without the status of a legal entity is a family member specified in the contract (declaration) on establishment of a family farm, which should register as an individual entrepreneur. Corresponding amendments were introduced to the Law of Ukraine No. 755-IV «On State Registration of Legal Entities, Individual Entrepreneurs and Public Organizations» of May 15, 2003 - the information on establishment of a family farm by an individual entrepreneur is now entered the Unified State Register.

The Law of Ukraine No. 2497-VIII «On Introduction of Amendments to the Tax Code of Ukraine and Some Other Laws on Stimulation of Establishment and Operation of Family Farms» of July 10, 2018 also introduced amendments to the Tax Code of Ukraine. In particular, the $4^{\text {th }}$ group of single tax payers now includes individual entrepreneurs in addition to legal entities subject to a number of requirements, such as cultivation of agricultural plants, breeding, gathering, fishing, processing of cultivated plants or bred livestock and sale of them; non-exploitation of hired labour; the area of agricultural lands and/or water reserve lands owned and/or used by family farm members should be over 2 ha, but less than 20 ha. Moreover, this Law expanded the sphere of state support of family farming - in addition to the types of support envisaged by the Law of Ukraine «On the State Support of the Agriculture of Ukraine», family farms registered as single tax payers of the $4^{\text {th }}$ group receive additional financial assistance through the mechanism of partial compensation of the 
unified contribution for compulsory state social insurance for the benefit of insured persons - members/head of a family farm household - in the amount of: 0,9 of the minimum insurance contribution in the first year; 0,8 of the minimum insurance contribution in the second year; 0,7 of the minimum insurance contribution in the third year; 0,6 of the minimum insurance contribution in the fourth year; 0,5 of the minimum insurance contribution in the fifth year; 0,4 of the minimum insurance contribution in the sixth year; 0,3 of the minimum insurance contribution in the seventh year; 0,2 of the minimum insurance contribution in the eighth year; 0,1 of the minimum insurance contribution in the ninth and tenth years. The financial assistance is paid out of the funds of the state budget of Ukraine and is provided to the family farm exclusively on condition that the head of the family farm pays for himself/herself and each family member a unified contribution for compulsory state social insurance in the amount not less than the specified share of the minimum insurance contribution if they are not subject to insurance on other conditions.

Therefore, the legal framework for functioning of family farms has undergone essential positive changes in the recent years. Now, family farms are full-fledged agents of the market relations.

However, the process of evolvement of family farming is still very slow. As it was mentioned before, the basis for creation of such family farms is represented by private farm households. According to the results of the survey of owners of private farm households in Lviv region, only $11,0 \%$ of respondents consider the possibility to transform their farm households into family farms. In the opinion of most respondents, instability in the country is the main factor that hinders the development of family farming in Ukraine. Proper state financial support would prompt $60,2 \%$ of respondents to create a family farm (figure 1).
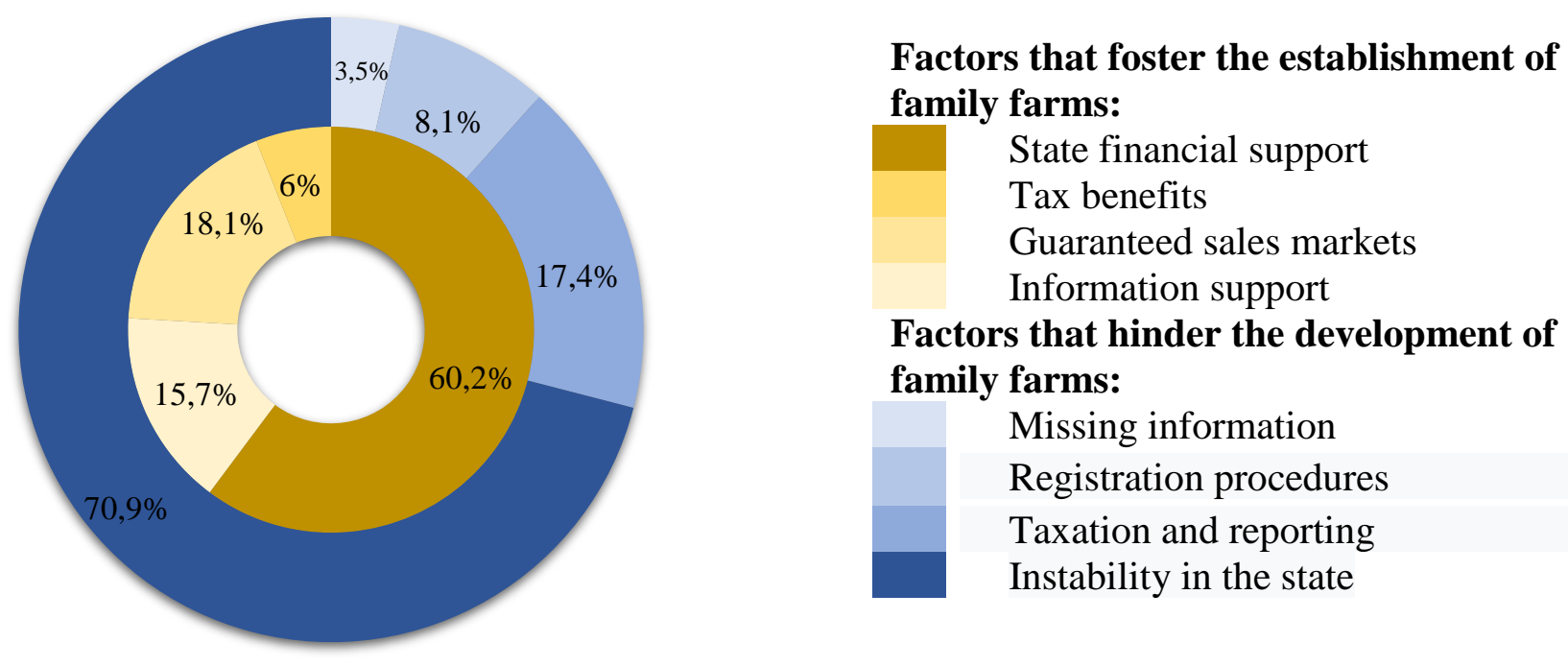

Fig. 1. Results of the poll of owners of private farm households on prospects of creation of family farms 
Thus, efficient steps of the state authorities are required for activation of the process of transformation of private farm households.

In line with the Decree No.664-p of the Cabinet of Ministers of Ukraine «On Approval of the Concept of Development of Farming and Agricultural Cooperation for 2018-2020» as of September 13, 2017, the priority of support of farms should be guaranteed by way of creation of favorable conditions for initiation and effective pursuit of the farming activity, in particular transformation of private farm households into family farms, engagement of young people in the farming activity. Stimulation of the process of establishment of new farms was identified as one of the main directions of the planned state financial assistance to family farms. However, the mechanism of financial motivation of establishment of such farms is still absent.

It is obvious that Ukraine should leverage the experience of European countries in stimulation of development of family farming. We should especially pay attention to the experience of Poland as our closest neighbor and partner in realization of European integration processes. There is a number of current projects of support of family farming in Poland, including «Restructuring of small households», «Grants for young farmers», «Grants for initiation of non-agricultural activity», etc. (Rural..., 2014). For example, the grant for young farmers in the amount of 100000 PLN is awarded to persons aged 18-40 who are citizens of an EU members state, have professional qualification and work experience in the agriculture, started agricultural activity not earlier than 24 months before the date of submission of the application, have a farm household with the area of at least 1 ha, have not applied for direct payments, financial assistance for farmers under EU support schemes or for the national aid, as well as submitted a business development plan.

Moreover, Poland uses a simplified system of direct payments to agricultural producers. In particular, the total amount of direct payments allocated by the Ministry of Agriculture and Rural Development in 2018 constituted 14.8 billion PLN (single payment for the used land area - 459,19 PLN/ha, subsidies for pulse crops (up to 75 ha) - 721,04 PLN/ha, for pulse crops (over 75 ha) - 360,52 PLN/ha, for hop 2129,87 PLN/ha, for starch potato - 1065,89 PLN/ha, for sugar beet - 1495,63 $\mathrm{PLN} / \mathrm{ha}$, for tomatoes - 3320,78 PLN/ha, for strawberry - 1054,35 PLN/ha, subventions for cattle - 293,04 PLN/ha, for cows - 373,70 PLN/ha, etc.) (Mikos, 2018). In addition, Poland implements projects aimed at development of knowledge and professional skills of farmers and owners of forests in the sphere related to agricultural activity and forestry. Consulting plays an important role in support of agricultural producers. We believe that the use of the experience of Poland in support of family farming would yield a positive result in the process of transformation of private farm households into family farms.

The authorities in Ukraine are lobbying the interests of big agricultural businesses, leaving small farmers at their own expense. Currently, the purpose of supporting family farms as a necessary and promising form of farming in rural areas is not provided in either the state or local budgets. 
We believe that the process of establishing a family farm in Ukraine at the state level requires the development and implementation of a system of measures aimed at creating favorable institutional and economic conditions for the development of family farms. First of all, it is necessary to create a mechanism of state financial support for the transformation of personal farms into family farms, in particular, to develop and approve a program of support for young farmers, a program of lending to new farms, etc. An obvious impact on the creation of family farms will be the introduction of the possibility of registration of the economy on the principle of "one application", as well as differentiation of approaches in taxation of large and small agricultural producers. In addition, it is necessary to initiate at the state level the creation of marketing and processing agricultural service cooperatives, which would enable the family farms to supply the produced products, facilitate the access of the newly established family farms to land and natural resources, as well as provide information support and advisory services.

\section{Conclusions}

Formation of productive family farming is a key to development of the agrarian sector of the economy and rural territories. The legal framework of family farming in Ukraine has been actively developed within the recent years.

Absence of efficient incentives for transformation of private farm households into family farms is the main reason for slow development of family farming. So far, provision of the additional assistance for payment of the unified contribution for compulsory state social insurance and recognition of family farms as agricultural producers and single taxpayers of the $4^{\text {th }}$ group still remain the only legally established incentive measures.

Incentives that will foster transformation of private farm households into family farms include the development and approval of financial support programs, guaranteed access to markets and land resources, information support, tax preferences, etc. We should also consider the experience of the EU countries, and Poland in particular, in support of small rural households.

The proposed measures can make family farming attractive for owners of private farm households, for young people, and will foster establishment of family farms, thus allowing to save the future of the Ukrainian village.

\section{References}

Borodina O., Shubravska O. (2018). Agrarian and Rural Development for the Growth and Renovation of the Ukrainian Economy. - Kyiv, The Institute for Economics and Forecasting of the National Academy of Sciences of Ukraine. 152 p.

Dolynska M. (2017). Novelties of the Legislation on Establishment of Family Farms in Ukraine // Herald of Lviv Polytechnic National University. No. 865: 392-397.

Graeub B.E., Chappell J.M., Wittman H., Ledermann S., Bezner Kerr R., Gemmill-Herren B. (2016). The State of Family Farms in the World // World Development. Vol. 87: 1-15. 
Hubeni Yu., Koverko Yu. (2016). Development of Private Farm Households at the Threshold of Institutional Changes. - Lviv. Ukrainian Technologies Scientific and Production Company. 186 p.

Khrypko S. (2015). Family Farming: Problems of Legal Regulation // Pidpryiemnytstvo, hospodarstvo i pravo. No. 9: 36-39.

Korinets R., Malik L. (2018). Institutionalization of Family Farms in the Socio-Economic Environment // Ekonomika APK. No. 4: 60-69.

Koverko Yu., scientific research «Problems and perspectives of private farm households at the threshold of institutional changes» (by President's of Ukraine grant for competitive projects F63 of the State Fund for Fundamental Research, 2016).

Lushpaiev S. (2018). Novelties of the Legal Status of Family Farms // Pidpryiemnytstvo, hospodarstvo i pravo. No. 10: 104-107.

Malik M., Shpykuliak O., Mamchur V. (2018). Institutional Formalization of Development of Family Farming in Ukraine // Ekonomika APK. No. 10: 72-85.

Mikos P. (2018). Direct Payments - What Will Be the Rates per 1 Hectare in the Season of 2018/2019? - https://www.tygodnik-rolniczy.pl/articles/aktualnosci_/doplaty-bezposrednie-jakiebeda-stawki-za-1-ha-w-sezonie-20182019/

Regulation (European Union) No.1307/2013 of the European Parliament and of the Council of 17 December 2013 establishing rules for direct payments to farmers under support schemes within the framework of the common agricultural policy and repealing Council Regulation No.637/2008 and Council Regulation No.73/2009 (2013). - http:// https://eur-lex.europa.eu/legalcontent/EN/TXT/?uri=celex:32013R1307

Rural Development Program for 2014-2020 (2014). - https://www.arimr.gov.pl/pomocunijna/prow-2014-2020.html

Urkevych V. (2016). Legal Aspects of Establishment and Operation of Family Farms // Scientific Herald of the National University of Life and Environmental Sciences of Ukraine. No. 243: $67-75$.

Zaleckienė J., Vilkevičiūtė J., Linkevičiūtè S., Koloszko Chomentovska Z. (2018). Farmer's entrepreneurship: case of Lithuania // Management Theory and Studies for Rural Business and Infrastructure Development. Vol. 40. No. 2:283-296. 